\title{
Crucifiction? The Reimagination of Crucifixion as Failed Imperial Ritual in Philippians 2:5-11
}

\section{Peter-Ben Smit}

Peter-Ben Smit, Dr. theol (New Testament), Dr. theol. habil. (Church history) both University of Bern; Th.D. in Anglican Studies (General Theological Seminary, New York) is extraordinary professor of Ancient Catholic Church Structures and the History and Doctrines of Old Catholicism at Utrecht University, assistant professor of New Testament at the Vrije Universiteit Amsterdam, research associate at the Faculty of Theology of the University of Pretoria, and assistant priest in the Old Catholic parish of Amsterdam. Recent publications include From Canonical Criticism to Ecumenical Exegesis? (Leiden: Brill, 2015) and Paradigms of Being in Christ: Paul's Use of Exempla in Philippians (London: Bloomsbury, 2013).

\section{Abstract}

In this paper the famous "hymn" in Philippians 2:5-11 is considered from the perspective of the study of ritual failure. It is argued that the crucifixion of Jesus, as it is mentioned in this text, can well be considered as a ritual that, on the one hand, fails, given that it leads to Jesus' exaltation rather than to his permanent death, while it is at the same time reinterpreted as a consequence of Jesus' obedience rather than of his disobedience, as one would expect. Using the body of theory as it has been developed concerning ritual and its failure, it is shown how this reinterpretation of a ritual is more than "just" about ritual, but serves to carve out a space for early Christianity and its selfunderstanding in the web of power relationships that made up Greco-Roman society.

Key words: crucifixion, Paul, Philippians, ritual, ritual failure, New Testament

\section{Introduction: Reframing Ritual and the Early Christian Negotiation of Their Minority Position}

Early Christians were a minority within a minority in the Greco-Roman world, specifically within the Roman Empire. Nonetheless, they laid claim to worshiping a God, notably the deity of choice of a subjugated people, who had raised a person, in whose body Roman imperial power had been inscribed until his death, i.e. the crucified Jesus of Nazareth, to new life, thus voiding this imperial power. This led to a peculiar situation in which early Christians had to negotiate the tension between the sociological reality of being a (marginalized) minority and their claim to belonging to the ultimate majority in terms of worshiping the one true God, the creator of heaven and earth. This paper explores this tension by asking the question how early Christians, themselves cultural, ethnic, and religious hybrids, used to inhabit multiple worlds at once, sought to negotiate and reinterpret the central symbol that indicated, from the perspective of the majority of the Greco-Roman world, their marginalized position and from their own perspective their claim to eventual victory: the cross and the process of crucifixion. This process of negotiation and resulting reinterpretation is analyzed specifically from the perspective of the study of rituals in the Greco-Roman world, within which the notion of "ritual failure" and the resulting process of ritual negotiation, can be used to explore the dynamics of the reinterpretation of the cross and the crucifixion as the (failed) ritual performance of Roman imperial power by early Christians, especially in the "hymn" found in Philippians 2,5-11. Thus, light is shed both on the role played by the reinterpretation of public rituals and symbols by marginalized minorities with high claims to (eventual) truth and power in the process of their 
negotiation of the tension between sociological reality and religious claims, and on the selfpositioning of a particular minority in the Roman Empire as such. In addition, employing the perspective of the study of ritual failure provides an innovative perspective on both of these topics.

In this paper, therefore, I analyze the presentation of Christ's crucifixion in Phil. 2:5-11 from the perspective of the study of "ritual failure" and the closely related perspective of "ritual negotiation." These perspectives originate from the broader field of ritual studies, which is slowly making an impact on the study of the New Testament, but have yet to be used at a larger scale in relation to New Testaments texts. When considering crucifixion as a ritual, which has not been done very often, Phil. 2:5-11 provides an interesting opportunity for considering it as a failed ritual, given that there, crucifixion does not lead to permanent death, as it "should," but rather to new and glorious life - at the very least this is a striking instance of reinterpretation of crucifixion, one that requires the reimagination of the entire fabric of society, as will be argued below; an instance of crucifiction, indeed; hence the neologism in the title of this paper. In order to achieve this and to provide an answer to the question "can the presentation of the crucifixion of Christ in Phil. 2:5-11 be understood as a case of the renegotiation of the meaning a ritual, due to ritual failure and, if so, what perspectives does this provide for the interpretation of the text?", first a brief discussion of the understanding of ritual of this paper will be presented, followed by an outline of the theory of ritual failure, a discussion of crucifixion as a ritual, before proceeding to an interpretation of Phil. 2:5-11 on this background, and offering final conclusions.

\section{Rituals and Ritual Failure}

As can be easily observed, ritual studies and ritual criticism are slowly beginning to have a larger influence on New Testament studies (see: Uro:2020, Lamoreaux:2009). This is to be welcomed, as the study of rituals addresses an important aspect of many New Testament texts: So many texts are related to rituals, such as circumcision, sacrifice, baptism, and ritual meals. Even if the historical rituals to which New Testament texts refer are no longer directly accessible - as are all historical events "behind" the texts - the study of their probable shape and functioning can still inform the exegesis of the texts themselves. This is of significance, given that many early Christian texts are concerned with ritual. In fact, as will be argued below, many of the New Testament texts about rituals can be understood, not only as texts "about" rituals, but also as part of a community's ritual praxis itself or a community's interpretation of a ritual praxis, given that the evaluation of a ritual belongs to such a ritual praxis (see the criteriology of Strecker:1999, 78-80 followed by DeMaris:2008, 5-6). In other words: A text like 1 Cor. 11:17-34 is not just about "how Christians should celebrate a meal", or what the meaning of this meal is, but, precisely because it asks questions about ritual, about "who Christians are." The same applies to a text like Phil. 2:5-11: It is not just a text that says something about how crucifixion functions, but it also expresses who Christians are as followers of the crucified (and exalted) Christ (see also: Smit:2013a). Rituals are, therefore, more than just an expression of something else in symbolic form (see Eliade:1961). This is in line with more recent theorizing about rituals, in which their own character, notably in relation to the body, to bodily experience, and to enactment as a fundamental mode of identity, has been stressed, e.g. by scholars such as Grimes, Bell, and Rappaport. Rappaport, for example, argues the following:

Ritual is not merely another way to "say things" or "do things" that can be said as well or better in other ways. The form that is ritual is surely without communicational equivalents and thus, possibly, without functional or metafunctional equivalents. That ritual's abilities are intrinsic to its form an in indissoluble association only with its form, goes far to account for is ubiquity. (Rappaport:1999, 138) 
Given this background, the "rediscovery" of ritual in early Christian studies has rightly underlined the importance of rituals such as baptism, meal fellowship, circumcision, etc., and the reflection upon them for the development of early Christian identity. Through the enactment or performance of a ritual, a community's identity is set in scene and reconstituted (see: Lieu:2004, 147-211). What is enacted may be described as the "script" or "grammar" - terms that are equivalent in this context of a ritual. In the study of rituals, as well as in their actual functioning, these notions indicate a set of rules, which can be more or less elaborate, according to which a ritual needs to proceed in order to function. Paying attention to this "script" or "grammar" is helpful, both because it helps to shed light on a ritual's structure and because it provides a starting point for the analysis of a ritual:

ritual behaviour is structured and ... many of these structures can be represented in such a formalised way that general rules surface. The description and analysis of these structures and rules are nothing else than a grammar, the grammar of rituals... (Michaels:2012, 11)

This grammar, especially as it is used, explicitly or implicitly, by a community performing a ritual, also contains ascriptions of meaning to (parts of) a ritual, as well as expectations about the (desired) outcome of a ritual (on this, see: Michaels:2010). In this way, the notion of a ritual "grammar" goes beyond being a "mere" set of rules concerning ritual actions and makes perspicuous why also the evaluation of a ritual is an inherent aspect of its performance. When using the notion of "grammar" in the sense proposed by Michaels, the impression that a ritual "grammar" is entirely static can be avoided: it can change, even if it does so at a slower pace than its sequential performances. One reason for a grammar to change or be changed is precisely ritual failure and resulting ritual negotiation, as will become clear below. At the same time, due to its function as the set of norms inherent to the ritual, the grammar can also provide a corrective to particular kinds of its performance, should they be perceived as "failures" or "mistakes" when compared to earlier versions of the ritual or to its significance (Hüsken:2007, 337) In this way, a ritual grammar functions just like the grammar of a language. The grammar of a ritual, whether it is explicit or not, therefore plays a major role in the evaluation of a particular performance of a ritual.

At this point, a potential criticism of the use of modern theories, such as theories concerning rituals and, below, ritual failure, to ancient texts, such as Phil. 2:5-11, namely the question as to the appropriateness of such a potentially anachronistic approach. While this question is certainly legitimate, it may also be considered answered by the productive contribution that has been made by the application of sociological models to the study of the New Testament in general (see Strecker:1999, 23-31; Elliott:1993). The danger of anachronism, which lurks whenever a new model is applied to an old text, can be avoided by ensuring that the results from the (primarily heuristically oriented) use of a particular model in the exegesis of a text do indeed have a basis in the text itself and not in the model only. With regard to ritual criticism in particular, it may be noted that this field of study generally assumes the transcultural character of particular ritual patterns, which also legitimates the use of models stemming from the analysis of one culture or cultural group for the analysis of rituals of another culture or cultural group.

Having outlined all of this, the notion of "ritual," as it was introduced above, can be specified somewhat more. A starting point can be found in Becker's statement that "Ritual refers to an elaborate sequence of individual rites which, following an established ritual syntax, are logically connected within a certain functional context." (Lamoreaux:2009, 154) Such an understanding, which depends on the notion of "script" or "grammar" as outlined above, can be developed further with the help of the theoretical framework provided by Michaels, who argues that rituals can be understood to to have the following five characteristics: 1) Rituals are always related to causal 
change (causa transitionis), pertaining to circumstances that can be biological, physical, social, or natural in character; 2) A ritual is always intentional: some kind of ritual intention needs to be there and be expressed (solemnis intentio), examples are oaths, vows, promises, or verdicts; 3 ) A ritual is characterized by certain formal criteria of action, i.e., in order to be a ritual, an action must be stereotypical, formalized, repetitive, public, irrevocable, and often liminal (actiones formaliter riterorum); 4) Rituals are always contain modal criteria of action (actiones modaliter ritorum), expressing the functional dimension of rituals, pertaining either to "societas" (functions of ritual relating to society: solidarity, hierarchy, control, standardization, etc.), "religio" (rituals performed because of the transcendental value attached to them), or "impressio" (rituals understood in relation to the emotions of participants) ; 5) Rituals are related to change in identity, status, role, or competency (novae classificationes, transitio vitae) (Michaels:1999).

All of the above considerations lead to a situation in which, in order to arrive at a satisfactory ritual exegesis of a text, one needs, apart from the identification of something as a ritual and an awareness of the interrelationship between ritual and identity, also a script and a particular performance of that script, a way of interrelating the two, and an awareness of what script is being related to what performance. With regard to this, difficulties lay not only in determining which script is relevant in what way, but also in reconstructing it appropriately. Depending on one's expectations, also with regard to the effect and outcome of a ritual and determined largely by the "grammar" or "script" that one had in mind, a ritual would be deemed a failure or a success. Having outlined this, now the specific categories of "ritual failure" and "ritual negotiation" can be addressed.

\section{Ritual Failure and Ritual Negotiation}

Ritual failure refers to cases in which a ritual is imperfectly performed, giving rise to its discussion and (re)negotiation in relation to the ritual community's developing identity (= "ritual negotiation") (See: Hüsken/Neubert:2012, for the following see also the presentation in Smit:2013b). A fledgling field itself, this approach to rituals, especially as it is understood in this contribution, has yet to begin to be introduced in New Testament scholarship.

Rituals may fail due to a number of reasons, all related to the "grammar" or "script" of the ritual, including expectations with regard to its procedure, the persons and items involved, and the outcome. A broadly received proposal for the classification of ritual failure has been introduced by Grimes (Grimes:1990), who is widely regarded as one of the most important and influential theorists in the field of ritual studies. The typology that he offers includes a variety of kinds of failures that are not (mutually) exclusive; also, a ritual can be successful on one level for some and a failure on another level for others (e.g. a fertility ritual that fails to produce fertility, but does contribute to group cohesion). According to Grimes (Grimes:1990, 204-205), the following cases of ritual failure can be distinguished:

1. Misfire (act purported but void)

1.1. Misinvocation (act disallowed)

1.11. Nonplay (lack of accepted conventional procedure)

1.12. Misapplication (inappropriate persons or circumstances)

1.2. Misexecution (act vitiated)

1.21. Flaw (incorrect, vague, or inexplicit formula)

1.22. Hitch (incomplete procedure)

2. Abuse (act professed but hollow)

2.1. Insincerity (lack of requisite feelings, thoughts, or intentions)

2.2. Breach (failure to follow through) 
2.3. "Gloss" (procedures used to cover up problems)

2.4. "Flop" (failure to produce appropriate mood or atmosphere)

3. "Ineffectuality" (act fails to precipitate anticipated empirical change)

4. "Violation" (act effective but demeaning)

5. "Contagion" (act leaps beyond proper boundaries)

6. "Opacity" (act unrecognizable or unintelligible)

7. "Defeat" (act discredits or invalidates of others)

8. "Omission" (act not performed)

9. "Misframe" (genre or act misconstrued)

This classification provides a useful starting point for the analysis of ritual failure in Phil. 2:5-11. First, however, some further observations with respect to the nature of ritual failure should be made.

To begin with, respect to the process of the analysis of ritual failure, it is of importance to note that the evaluation of rituals is an inherent part of the communities performing them:

"Evaluation is an intersubjective process, executed by groups or individuals. It is based on certain sets of values which might stem from canons which the participants themselves have not created, but it might equally be based on the expectations, intentions and agenda of individual participants..." (Hüsken:2007, 339) Or, as Grimes has it: "Ritual criticism goes on informally all the time, and its contexts are various - both popular and scholarly. Criticism is not restricted to scholars. Ritual criticism is implicit in the normal course of conserving, transmitting, enculturating, and adapting rites." (Grimes:2004, in Hüsken:2007, 339) In other words: the attribution of failure or success to a ritual is not an extraneous scholarly classification, but inherent to the ritual and its performance (Hüsken:2007). This notwithstanding: a ritual can fail for outsiders in some ways in particular, for example because it is unintelligible to them (category 6 "opacity"), or because it constitutes a violation (category 4), which may not be the case for those actually engaged in the ritual; also "misframing" (category 9 ) is a category particularly relevant for outsiders evaluating a ritual - but not only for them. At the same time, a ritual can fail and be successful simultaneously depending on the criteria that are applied in its evaluation (Hüsken:2007, 353.361). With regard to the latter, it should be stressed that a ritual always fails for particular people and from a particular perspective, i.e. it can be successful for some while it is a failure for others - in the case of crucifixion, for example, when understanding it as a ritual, it may be spectacularly successful as a ritual performance of imperial dominance from the perspective of some, while may just as spectacularly fail due to "violation" (see above) from the perspective of others.

Furthermore, as Hüsken, has pointed out, based on the analysis of a collection of studies on ritual failure, cases of rituals going awry contribute much to the discovery of the meaning of a ritual for a community and to the further development of the rituals as such. As she states:

[P]articipants and spectators alike learn more about the 'correct' performance of a ritual by deviating from, rather than by adhering to the rules. One might even say that solely the definitions and examples of 'ritual failure' and 'error' - and how they are coped with - prove the existence of decisive norms for ritual actions, even when the former are imagined deviations from imagined norms. (...) 'Failed ritual' directs our attention to 'what really matters' to the performers and participants and others in one way or another involved in a ritual. (Hüsken:2007, 337) 
Another aspect of the dynamics involved in the detection and discussion of ritual mistakes or ritual failures that is of significance, is that of the ritual competence that performers of rituals and/or its critics have (or claim) and/or deny others. Only "ritual specialists" may be seen to have the right to deviate from ritual norms, others may be regarded as lacking this specific authority (Hüsken:2007, 334-346.361). As Hüsken points out:

Frequently, if not always, the social and political standing of individuals and groups beyond the ritual context are negotiated through the evaluation of ritual. Not only the ritual process, but also the authority and authenticity of the ritual experts, and hierarchies among the participants (or the groups which are represented by them) are evaluated and, eventually, reorganized. Moreover, whose definition of 'right' and 'wrong' has a lasting impact on a ritual tradition reveals how the power relations in the wider socio-cultural field are structured. This close connection of ritual and its [social] context accounts for the fact that deviations from a prescribed ritual procedure are often purposely employed in order to challenge the form of the rituals and through it the prevalent power relations as well. (Hüsken:2007, 361-362)

Finally, the "creative power of deviations" should be considered (Hüsken:2007, 346-347). This is an important aspect of the dynamic of "ritual failure," given that "breaches of [ritual] rules can - and frequently do - instantiate the creation of new ritual rules in practice." (Hüsken:2007, 346) Of interest is also Hüsken's remark that such creation of new ritual rules takes place "frequently under the pretext of 'returning to older (severer) rules.'" (Hüsken:2007, 346) Thus, the breaking of ritual rules and their correction, can be seen as a creative process as well, in which new ritual forms are created, or new meaning is given to rituals. This creative aspect of ritual failure is closely related to the second aspect of ritual studies that is of significance here: "ritual negotiation" that will be introduced now.

"Ritual negotiation" has been described by Hüsken and Neubert as the process of "interaction during which differing positions are debated and/or acted out" in relation to a particular ritual and the community performing it, noting that "a central feature of ritual is its embeddedness in negotiation processes, and that life beyond the ritual frame often is negotiated in the field of rituals." (Hüsken/Neubert:2012 , 1) These insights further develop three aspects of what is already brought to the fore by the study of ritual failure:

a) the importance of rituals as a focus for the (re)negotiation of the life of a community or group;

b) the significance of power relations with regard to the performance and criticism of ritual;

c) the importance of (perceived) failure and disagreement for triggering critical thinking and reflection. (Hüsken/Neubert:2012, 1-4) It goes without saying that such (re)negotiation of rituals also points to the often masked but fundamental instability and fluidity of rituals and their performance. Initial explorations in the field of "ritual negotiation" have led to the identification of three main themes associated with it:

1) Questions of participation, both in the ritual as well as in processes of negotiation regarding it often are of central importance;

2) Questions relating to the "subversion of ritual prescriptions, ritual roles, and the power relations surrounding the ritual performances" (Hüsken/Neubert:2012, 1) often seem to be the trigger of processes of ritual negotiation; 
3) Questions concerning the context of a ritual, specifically the web of social (power) relations within which it has a place and the kind of differences it negotiates move to the foreground more when processes of ritual negotiation are taken into account.

On this basis, it is now possible to turn to, first, crucifixion as a ritual performance of Roman imperial power and, subsequently, to its failure according to Phil. 2:5-11.

\section{Crucifixion as Ritual Performance of Imperial Power}

Crucifixion, of course, can be considered as simply one among many more or less cruel forms of execution (see: Carter:2013, 87-106; Hengel:1976, 25-84; Chapman:2010; Samuelson:2011;

Cook:2014; Finney:2013). Leaving one's understanding of the crucifixion at that, however, would overlook the ritualized character of most, if not all forms of public execution, both in actual practice and, just as relevant, in their literary and pictorial representation, given that it is through these representations that (further) meaning is attributed to these executions and that there future (ritualized) performance is framed. However, there is more: what remains striking about crucifixion as a form of public execution is its particularly labor-intensive character. Surely, there are easier and logistically more convenient ways of disposing of someone; hanging, decapitation, drowning, cutting someone's throat, etc. all require much less effort than a crucifixion, which not only requires a cross, but also a process of attaching someone to a cross, subsequently a guard to make sure that the protracted process of expiring is not disturbed, and possibly the effort of breaking (leg) bones in order to speed up this process. Furthermore, crucifixion, certainly of individuals, was often preceded by the equally labor intensive process of public whipping, or other forms of humiliating and emasculating treatment. If one adds to this the use of signs (tituli), indicating publicly why a person was crucified, the observation that all of this was intended for public display, to achieve the public humiliation of the victim and the "edification" of the onlookers, and the fact that execution by crucifixion occupied a particular place on the scale of shameful ways of dying, the impression is hard to escape that there is more to execution by crucifixion than just another form of putting someone to dead. Thus, following a more or less clear pattern, crucifixion can be seen as having a ritual and symbolic quality, dramatically enacting who was in charge and could do whatever he liked with another person. (Horsley:2005, 6-7) As Wright has put it:

As everyone in the Roman world knew well, the cross already had a clear symbolic meaning; it meant that Caesar ruled the world, with cruel death as his ultimate, and regular, weapon. For Paul, throughout his writings, the cross is far more than simply the means whereby individual sins are forgiven, though of course it is that as well. It is the means whereby the powers are defeated and overthrown (1 Cor. 2:6-8; Col. 2:13-15). The resurrection demonstrates that the true God has a power utterly superior to that of Caesar. The cross is thus to be seen, with deep and rich paradox, as the secret power of this true God... (Wright:2007)

In line with this, Malina and Neyrey rightly referred to the crucifixion as a "status degradation ritual." (Malina/Neyrey:1988, 69-92) These initial observations can be expanded further - the considerably curiosity of having a poetic text extolling a crucified Lord from a society in which the topic of crucifixion was considered to be unfit for polite conversation would invite one to do so. (Bockmuehl:1997, 139) To begin with, when using the understanding of ritual that was presented earlier, crucifixion can easily be classified as such, even if this is hardly ever done. (See Price:1997) Reasons for this include the following. When referring back to Becker's notion of ritual as referring "to an elaborate sequence of individual rites which, following an established ritual syntax, are logically connected within a certain functional context." (Lamoreaux:2009, 154) Crucifixion, with its 
various elements (as listed above), clearly following a certain logic and fulfilling the (social - and even religious; it is hard, if not impossible, to distinguish between these two when it concerns transcendentally legitimated authority, as in the case of the authority of empire or of YHWH) function of ritually performing, using the body of the victim as the ritual "matter", the dominance of Rome. Also when turning to Michaels five characteristics of ritual (Michaels:1999), crucifixion easily fits into this mold. First, that crucifixion pertains to causal change hardly needs a substantiation, given that both physical changes (in the victim) and social changes (through the victim's utter degradation exclusion from society) are obviously effectuated through the ritual. Second, that there is a ritual intention is equally obvious: crucifixions do, usually, not happen spontaneously, but as a result of a verdict. Third, the stereotypical, public, largely formalized, repetitive, irrevocable, and liminal characteristics of the actions that constitute crucifixion is also perspicuous. Fourth, the modal character of crucifixion qua ritual can also be considered clear, given its social and religious aspects and functions. Fifth, crucifixion clearly causes a change in identity and status, given that someone is so thoroughly stripped of any social status that the result is utter humiliation and death; in the case of the canonical gospel accounts, in the case of the accounts of Jesus' execution in the canonical gospels, for example, this amounts to a transition from "King of the Jews" to nothingness.

Having thus established the ritual nature of crucifixion, the analysis can be furthered, when noting that Bell has identified a particular category of rituals as political rites, which is are rituals that aim at displaying, promoting, and constructing political interests and, with that, power. (See Lamoreaux:2009, 157; Bell:1997, 128-129; Kertzer:1988, 2-8) Taking notice of this genre of ritual is helpful for understanding the ritual character of the crucifixion, given that it can be understood well as a ritualized, theatrical display of imperial power. This is the case in particular because the ritual was enacted on the orders of imperial authorities with as unwilling participants, i.e. victims, in particular those that upset the hierarchy of empire or flaunted the authority of Rome in a fundamental way. (See for a list of potential victims: Kuhn:1982, 719-745)

Beyond this, it may also be noted that torture as such, as which crucifixion, being a tortuous and humiliating way of dying, clearly can be classified, can be understood as having its own particular kind of rituality, particularly involving the exclusion of a person from society and even from being a human being through extreme non-recognition. (Kuch:2011) As Kuch notes:

Torture is not just about absolute power and absolute powerlessness, it is about demonstrating absolute power and being exposed in one's powerlessness. This exposed powerlessness, on the one hand, and the demonstrated power, on the other, is the humiliating truth of torture.... In this sense, torture has an essentially symbolic dimension. And this demonstration of powerlessness has to do with recognition, or, more specifically, with a loss of recognition. To be exposed in one's absolute powerlessness implies, precisely in its symbolic dimension, a radical loss of recognition. Autonomy, freedom, or agency are of central importance in our cultural values, and their loss may be a reason for far-reaching devaluation; that is, an extreme loss of recognition...[T]orture, then, is constitutively linked with symbolic, theatrical, or ritual elements as well as with the question of recognition and its loss. (Kuch:2011, 53)

It probably hardly needs any argument, also given the preceding observations, that this analysis of the rituality applies to crucifixion just as it applies to a variety of other forms of torture. In the case of crucifixion, a person that had flaunted imperial authority was dramatically and symbolically excluded from society and denied all humanity. This understanding of crucifixion as a ritualized form of torture is one final reason to understand crucifixion as a ritual, specifically as a political ritual and even more 
in particular as a ritual of torture. All of this remains true, even if the cautionary remarks of Samuelson are taken into account who refers to a rather vague range of "suspension" punishments that were available in the ancient world. (See: Samuelson:2011; Cook:2014) The precise mode of suspension and the terminology used for it, Samuelson's focus, and the unclarities regarding it do not render the social function of such executions or post-mortem public humiliation (whatever happened: the dying or dead body was put on public display - and often denied proper burial, notably not in the case of Jesus in the accounts of Mark, Matthew, Luke, and John - and a message was conveyed as to the public worth and status of this person). Notably, Samuelson does not consider the ritual aspects of the crucifixion.

On this basis, it is also possible to apply the insights of Butler concerning ritual to the crucifixion, following the lead of Beard and Georgia in this respect (Georgia:2013, 23; Beard:2007, 25). Butler notes that "ritual is material to the extent that it is productive, that is, it produces the belief that appears to be "behind" it." (Butler:1997, 25) In relation to rituals celebration Roman triump and dominance, Georgia takes this to mean that

The visual materiality of the triumphal ritual produced the 'belief' in Roman power, imperial divinity, and the global scope of Roman authority, but insofar as this materiality was constructed by foreign objects, people and symbols, the triumph itself became a complex of cultural exchange that could be exploited by Roman subjects even as they were exploited by Roman authorities. (Georgia:2013, 23)

The potential of the exploitation of this "cultural exchange" by the Roman subjects depended on two things. First, one needs to take into account the fact that one result of displaying power and dominance publicly, using the medium of the bodies of defeated and subjected people, always also means that these bodies are given center stage and are place into the spotlight. (Georgia:2013, 23) Of course, the intention of such a display was to underline Rome's control over these bodies. Nonetheless, the medium of the bodies as an interpretative surplus that cannot be controlled, or, put differently, and this is the second point, interpretation of such a theatrical display presents itself as a problem. Beard considers this to be a "central dilemma for triumphal celebrations" (Georgia:2013, 24 ) and notes that the question at stake is one that concerns all mass spectacles "how do you control the gaze of the viewer?" (Beard:2007, 136) Thus, putting one's dominance and power on display through the medium of the bodies of the defeated meant for a victor also to surrender (usually) himself to the evaluation of this display by the spectators, on which he depended for the public recognition of his victory, therefore depending on the medium of the bodies of his victims. The outcome of this process was never a certainty; through a different "reading" of the humiliated bodies of the defeated (e.g, as the undeservedly humiliated bodies of noble royalty, or the like), the persuasiveness of such a public ritual could well be undermined. Who saw what in the a theatrically and ritually celebrated victory was, therefore, of the utmost important, both for the victor putting on the display and for those seeing it. In particular, the question of interpretation was one of high importance for the associates (kinsmen, members of an ethnic group, clients, etc., etc.) of the person(s) whose body/-ies was/were used as the medium for the public display of triumph. As Meeks notes, in relation to the death of Jesus. As Meeks has noted "They faced a massive hermeneutical dilemma: interpret or despair. The movement did not despair. For the earliest formative remnant of them the paradoxical notion that God's anointed vice regent was ignominiously killed became the 
generative center of their beliefs." (Meeks:2007, 76-77, see also Georgia:2013, 17-18) Thus, recognized victory - and in a society so preoccupied with public recognition as the Roman one, only such victory was real in any meaningful sense of the word - depended to a large extend on the interpretation of the (bodies of the) defeated by the public. (Georgia:2013, 24) As soon as a ritual is performed publicly, therefore, a "a mimetic sequence of presentation and representation that subjects the spectacle to viewers who necessarily introduce their own hermeneutic" (Georgia:2013, $24)$ is initiated. This process and the ambiguity concerning the interpretation of the ritual that is produces are inherent to the way in which rituals function of rituals. (See Bell:1992, 184)

These last observations lead to a consideration of crucifixion as ritual failure in Phil. 2:5-11. As was already indicated, this text invites an analysis from that perspective, given that the outcome of the crucifixion in this text is strikingly different from what those ordering Jesus' crucifixion, (supposedly) in charge and control of it, will have intended. In this way, Phil. 2:5-11 is one of the earliest available literary representations of the interpretation of the ritual display of Roman victory over Jesus and his renewal movement within "colonialized" Judaism from the perspective of his marginal and defeated followers. It is evidence of the fact that the gaze of the onlookers could, in this case, not be controlled indeed. All of this makes it worthwhile to consider this process of interpretation of a ritual, leading to what can only be regarded as its failure from the perspective of its performers, from the perspective of ritual failure.

\section{Philippians 2 as a Case of Failed Imperial Ritual}

As was just outlined, specifically with regard to Roman triumphal rituals and the crucifixion, rituals are always in the process of being evaluated, especially when their outcome or performance does not agree with the expectations that one had of them or considered to be normative. The evaluation of a ritual is not fully controlled by those who perform it; as Beard has it, the gaze of the spectators is beyond such control. What comes out of the evaluation of a ritual, therefore, literally depends on one's point of view. In the case of Phil. 2, the ritual of the crucifixion that is considered in this text ( $\mathrm{v}$.

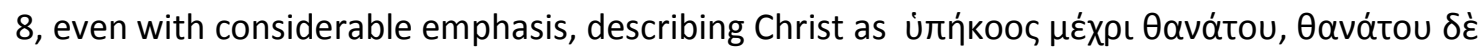

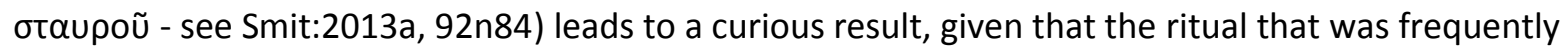
aimed at humiliating, punishing, and killing a disobedient slave (Kuhn:1982) becomes in this text the ritual, one would say: something like a rite of passage that leads to Christ's hyperexaltation by God because of Christ's obedience not disobedience to God. (Bockmuehl:1997, 140) Indeed, as Strecker has pointed out in relation to the crucifixion in other texts and distinguishing, with Foucault, between the a type of authority that is based on the power to destruct and destroy ("Souveränitätsmacht") and a kind of authority that is based on the power to transform and make alive ("Biomacht"): "mit der rituellen Aneignung des Kreuzestodes Jesu [wird] eine öffentliche Hinrichtung, das Schlüsselritual der antiken Souveränitätsmacht, letztlich in den Dienst des heilvollen Lebens gestellt."

(Strecker:2007, 152) Eliott puts it somewhat differently, but no less apt: "If God had raised to life a body pierced by Roman iron - a victim executed as an enemy of the Roman peace, and thus submitting to his people's tormented history - then the calculus of sacred violence that had made such an execution a terrible necessity, the calculus that had motivated Paul's persecution of the church, was destroyed forever." (Elliott:1994, 173) In other words, the ritual of crucifixion had failed and its meaning was renegotiated - from the perspective of early Christians, to be sure.

This can be considered from two perspectives, from the one, the crucifixion cum exaltation must appear as a failed ritual for a number of reasons from the perspective of the Roman authorities, given that it does not lead to the (permanent!) death and humiliation of the crucified, but to his exaltation to the very highest of honors. From the other perspective that takes precisely the crucified and exalted Christ as normative (see Phil. 1:1, 2:5), the ritual is not failed at all, but appears as the 
part of a broader dynamic, that of the enactment of the obedience until death of the cross and consequent exaltation of Christ. In fact, it can well be argued that familiarity with both of these perspectives is necessary to grasp any of the force of the enkomion in Phil. 2:5-11 (for form-critical considerations, see: Smit:2013a, 87). This text mimics the dominant ritual script with a twist (Peppard:2011, 130-131; Bhabha:1994), it subverts it in the process and replaces crucifixion as the imperial punishment for a disobedient slave with an understanding of crucifixion as a rite de passage

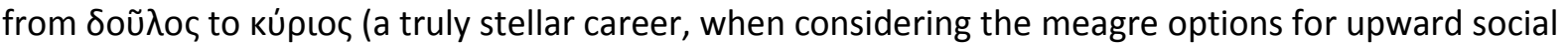
mobility of slaves during their own lifetime in Greco-Roman society), based on the utter obedience of

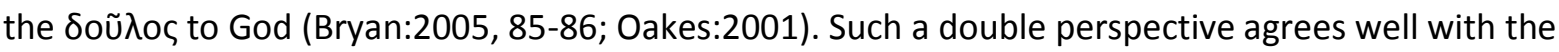
colonial situation that Paul found himself in and the hybrid identity that was his (Moore:2006 and 2011, Marchal:2011). Thus, one needs to know how the ritual of crucifixion could (and should) work from the perspective of the Roman authorities, i.e., as described above, resulting the (permanent) humiliated death of Jesus, leaving his corpse for the birds on the cross (Hughes:2014, 10), and one needs to know how it did work out in reality (assuming the perspective of the early Christian communities in which Phil. 2:5-11 was circulated), i.e. as a ritual indeed, but now of the exaltation of Jesus Christ and his endowment with the N/name above all names (Phil. 2:9-11), indeed, with a lordship which all acknowledge and proclaim; an interesting way of putting it, given that could also be a pars pro toto for a people, should this be in play here, then the victim of colonial powers becomes supreme colonial lord (see Hawthorne:1983, 93, noting that $\gamma \lambda \tilde{\omega} \sigma \sigma \alpha$ as in 2:11 can also denote "nation" or "people"). Christ's exaltation takes place at the point at which his corpse "should" have remained at the cross to decay and be eaten by scavengers. In fact, the latter interpretation leads to a complete reframing of what crucifixion is, leading to its failure from an imperial perspective.

All of this can be furthered, when it is considered that that Phil. 2:5-11 is a text that uses a public "script," i.e. that of the ritual of crucifixion, a notable and very visible instance of the public interaction of dominators with their subjects, and provides, in the private, or at most semi-public setting of the Christian congregation and Paul's correspondence, invisible to the eye of those in power publicly, an alternative performance of it (utilizing the medium of the text and engaging in mimicry, or repetition with a difference) and thus a critique of those dominators and their powers, it can be described as a "hidden transcript" as well, i.e. as an "off stage" and "camouflaged" way of resisting the publicly dominant Empire and its claims, in particular by mimicking it, but with a, literally crucial, difference that destabilizes the control that those performing the dominant public transcript have over their onlookers and (involuntary) participants, who, in their own space, enact a different transcript, hidden and subversive (Scott:1990, 3-4; Streett:2013; Horsley:2005; Van Henten:2009).

Having considered this, it is also possible to turn to the classification of ritual failure provided by Grimes, as it was presented above and consider which category or categories might help to further the understanding of the failure of the ritual of crucifixion in Phil. 2:5-11. To begin with, it is of interest to note a route that is not taken in Phil. 2:5-11: that of considering crucifixion a failed ritual performance of legitimate imperial power and authority due to its demeaning character (failure due to "violation", Grimes' category 7). This perspective would be readily available - for fairly obvious reasons - for members of the group of which a (leading) member was crucified. This, however, is not the case among early Christians, in fact, the demeaning character of the procedure of execution by crucifixion per se is unpacked nowhere - even if an awareness of its awkwardness is clearly present (e.g., 1 Cor. 1:23). Instead, a different route is chosen. This route consists of a number of different kinds of failure - from an imperial perspective - and of a complete reimagination and 
reinterpretation of what crucifixion amounts to as part of the narrative of the early Christian communities. The trigger of this process is none other than the realization, of whichever nature, that Jesus lives (again). The precise character of this realization is not to be discussed here, rather its effect on what the ritual of crucifixion and its failure amount to at this background when using Grimes' categories as heuristic tools. To begin with, crucifixion certainly turns out to have been an ineffectual ritual, i.e. it does not precipitate the anticipated empirical change (see Grimes' category 3 ), in the sense that Jesus does die, but his death turns out to be only part of his transition to new and glorious life - the most fullest acceptance and recognition possible, being elevated to the highest position in the social (or socio-religious) hierarchy imaginable. The notion that the "ritual execution" that is the crucifixion does not achieve its aim has its background in another part of understanding of what took place, from an early Christian perspective, at Jesus' crucifixion: its killing effect was "defeated" (Grimes' category of ritual failure 7), because this aspect of the crucifixion was

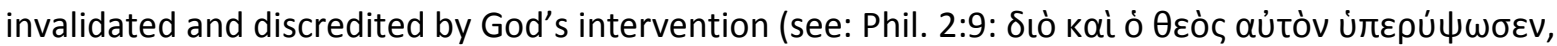
etc.). This also means that the ritual form of execution that crucifixion amounts to fails, in the sense that Jesus is raised to new life, despite its flawless execution; Jesus did die at the cross (note the

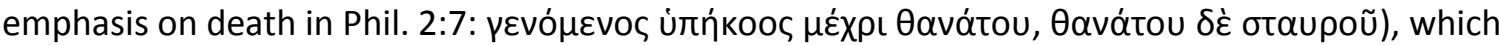
means that those executing it are left without an excuse, while, at the same time, the power of death (as it is at the disposal of the imperial authorities) is defeated. Thus, the implications of this particular kind of ritual failure go, in fact, beyond imperial authority as such: also the authority of death is challenged.

All of this implies a thorough "misunderstanding" or "misframing" (Grimes' category 9) of the ritual from an imperial perspective, which, indeed, leads to its failure from that perspective. This "misframing" is, in Phil. 2:5-11 most succinctly expressed by the complete reversal of the interrelationship of slavery-disobedience-crucifixion: instead of presenting slavery as involuntary but socially sanctioned loss of autonomy and freedom, a slave's disobedience as an unsanctioned protest against it, and crucifixion as the appropriate and socially sanctioned death-by-torture of a disobedient slave that reaffirmed the structure of society and denied such a slave any form of

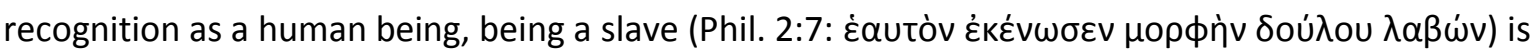
interpreted as a voluntary act (e.g., with emphasis on Christ's agency: Lohmeyer:1930, 93, followed by many others), an expression of active obedience, and this same obedience is seen as leading

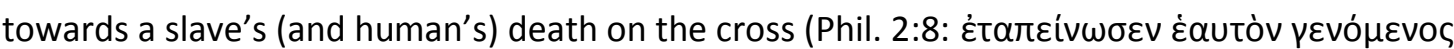

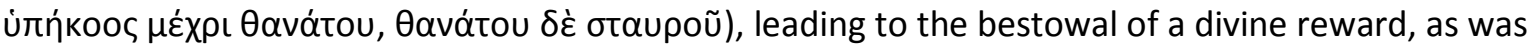
already outline (vv. 9-11 - see also Smit:2013a). Thus, what Paul expresses in 1 Cor. 1:23, indeed is also expressed by Phil. 2:5-11, what is a stumbling block to Jews and foolishness to Gentiles, is, indeed the power and wisdom of God. The reason for this is the radical reimagination of what crucifixion amounts to - this is possible because, given the post-crucifixion experiences of the early Christian community, in the eyes of this community, and beyond the view and reach of the performers of the ritual of crucifixion, indeed, as a hidden transcript, its interpretation spins out of control. Finally, the most practical aspect of all of this for the early Christian community, i.e. its empowerment by its reflection on the meaning of Christ's crucifixion, based on the revelation of the impotence of Empire and the potency of the colonial deity YHWH through it (and Christ's subsequent exaltation), can also be captured, from the perspective of empire, in terms of ritual failure. Given that crucifixion was designed to inculcate subjection, rather than empowerment, fear, rather than courage in those associated with whoever was crucified, and the obvious failure of crucifixion to 
achieve this in the case of Jesus and his followers, the ritual of crucifixion can be considered a "flop" (Grimes' category 2.4), given that it fails to achieve or produce the appropriate atmosphere and mood. In fact, because of the empowerment of the early Christian community that is the result of the (ritual) failure of the crucifixion, also the allegiances of the members of this community are realigned.

In this context, it may also be noted that what is described as happening to Jesus in Phil. 2:511 can very well be understood from the perspective of ritual studies as well, in so far as this field has been concerned with the role of rituals in transferring a person or a group from one identity to another one (e.g. from girl to woman, from deacon to priest, etc.), as this was emphasized by Michaels' fifth characteristic of rituals (see above). The process that a ritual governing the transition of one identity from another covers is often understood as consisting of a first phase, during which a person (in this case) is separated from a group, a second, liminal phase that contains the actual transformation of a person, and a third phase ('aggregation') that consists of the reintegration of the transformed person into a group again (see: Klostergaard Pedersen:2011, 21-24; Strecker:1999). When reading Phil. 2:5-11 from this perspective, a reasonable thing to do, given that someone clearly moves towards a new identity (see övo $\mu \alpha$ tò ùrè $\pi_{\alpha} \tilde{v}$ övo $\mu \alpha$ ) through a ritual (crucifixion, see above on its ritual nature). A moment of separation could, for example, be found in the first line of the

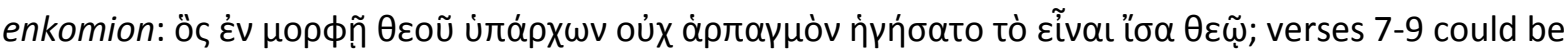
seen as a liminal phase during which through self-emptying, obedience and resulting death on the cross, and the reception of a new name a new identity is forged, while Christ, now adorned with the divine name, is reintegrated in the larger whole of the created order in verses 10-11 (aggregation).

On the basis of the above considerations, now further aspects of the dynamics that come into play when a ritual fails can be considered. These were outlined above, and notably involve (1) questions of participation in the ritual and its negotiation; (2) questions concerning power relations surrounding ritual performances; (3) questions concerning the context of the ritual and the web of (power) relations within which it takes place and is negotiated. Considering these various aspects of the process of ritual negotiation, it is clear that the question of power is a central one. The interpretation of ritual and the attribution of meaning to it always has to do with leadership and authority in the community performing it, on in which it is performed. When focusing on the crucifixion of Jesus Christ as it appears in the enkomion in Phil. 2:5-11, and assuming that the interpretation of the crucifixion that is presented in it is shared by both Paul and the Philippians (see, e.g., Smit:2013a), the community within which power relations are renegotiated is that of the Roman Empire as such. The reason why this is the case is simply that the crucifixion, the ritual enactment of imperial power par excellence is reinterpreted; had it been the sacrifices in the Jerusalem Temple, for example, then the relevant community would have been that of Judaism within the Roman Empire, but not of the oikoumene as such. If then, Jesus' crucifixion is presented as a failed imperial ritual of exclusion and humiliation on the one hand and as the instrument of the successful exaltation of the same person to divine glory by means of the same ritual by God (see 2:9), which power relations are questioned and, at least in textual and ritual form, renegotiated? In the end that what is questioned is the effective power of the Roman imperial administration to indeed definitely determine a person's ultimate fate and place in the whole of (socio-religious) reality, given that the ritual that was designed for this is presented as failed and reframed (misframed from an imperial perspective) in terms of a ritual of exaltation, probably at the background of early Jewish martyrological considerations (see for backgrounds: Van Henten:1997, Van Henten/Avemarie:2002), and, instead of utter social exclusion, one of utter social integration and elevation (Strecker:2007, 152) As part of 
this dynamic, also the power of death is challenged and questioned, given that death is also defeated by Jesus' elevation to glory by the God of Israel. When taking Phil. 2:5-11 on its word, in fact, the ritual that takes place there, the translation of Christ from self-emptying to glory by means of crucifixion, is, as it were, executed by YHWH, not by imperial agents, who are, with regard to this ritual, denied any agency and power. In fact, in the space of the early Christian community where the subversive transcript of Phil. 2:5-11 has been developed and is being performed, the imperial perspective on the crucifixion is denied all right to exist; it is not mentioned with a word. A bold claim is made in this way - and a bold reinterpretation of the structure of the world these early Christians lived in - a reinterpretation that has at its core the renegotiation of the meaning of a ritual: crucifixion, leading it to fail in one way and to succeed in another, highly unexpected way, due to a fundamental shift in the attribution of authority and agency (see on on empire and ritual: Chaniotis:2009, 5-17). Thus, whereas one authority is denied ultimate power, this kind of power is, at the same time, attributed to another authority. The reason why and how this happens has everything to do with another aspect of the dynamics of ritual negotiation, to this attention can be given now. Ritual and its renegotiation and reinterpretation is, in this case, clearly more about a kind of renewed signification (transsignification) of the whole of social, religious, and material (bodily!) reality, than "just a matter of ritual."

\section{Conclusions}

Conclusions can be drawn with respect to formal and material matters, i.e. with regard to method and content. They can remain relatively brief.

In terms of method, it has been shown that ritual theory and in particular theory concerning ritual failure provides a fitting and heuristically helpful tool to understand both the dynamics of crucifixion as such as well as to understand the dynamics that come into play when the ritual goes awry. This has been demonstrated above, especially in relation to the renegotiation of a majority ritual by a minority.

In terms of content, the use of ritual theory in order to analyze Phil. 2:5-11 has, to begin with, brought to light the ritual nature of this text, in the sense of it being an interpretative representation of a ritual, i.e. the crucifixion of Christ. Also, it has become clear how this text, as a Christological hymn that reinterprets and renegotiates what Christ's crucifixion amounts to, simultaneously reorders and renegotiates the structure of the entire social and socio-religious fabric of the GrecoRoman world, more specifically: of the Roman empire. It does so specifically by privileging the role of the God of Israel and reinterpreting the crucifixion of Christ as a ritual of exaltation rather than a ritual of humiliation. In doing so, early Christians also carved out a position for themselves in the imperial world as a whole and substantiated their following of a crucified slave as Lord.

\section{Bibliography}

Al-Suadi:2011, Soham Al-Suadi, Essen als Christusgläubige. Ritualtheoretische Exegese paulinischer Texte (Tübingen: Francke, 2011).

Barth:1979, Gerhard Barth, Der Brief an die Philipper [Zürich: TVZ, 1979).

Barton:2002, Stephen C. Barton, 'Social-Scientific Criticism,' in: Stanley E. Porter (ed.), Handbook to

Exegesis of the New Testament (Leiden: Brill, 2002)

Beard:2007, Mary Beard, The Roman Triumph (Boston: Belknap/Harvard University, 2007).

Bell:1992, Catherine Bell, Ritual Theory, Ritual Practice (New York: Oxford University, 1992).

Bell:1992, Catherine Bell, Ritual Theory, Ritual Practice (Oxford: Oxford University, 1992).

Bell:1997, Catherine Bell, Ritual: Perspectives and Dimensions (New York: Oxford University, 1997). 
Bhabha:1994, Homi Bhabha, 'Of Mimicry and Man: The Ambivalence of Colonial Discourse,' in: idem, The Location of Culture (London: Routledge, 1994).

Bockmuehl:1997, Markus Bockmuehl, A Commentary on the Epistle to the Philippians (London: Black, 1997).

Bryan:2005, Christopher Bryan, Render to Caesar: Jesus, the Early Church, and the Roman Superpower (Oxford University Press, 2005).

Butler:1997, Judith Butler, Excitable Speech: A Politics of the Performative (New York: Routledge, 1997).

Carter:2013, Warren Carter, Seven Events That Shaped the New Testament World (Grand Rapids: Baker, 2013).

Chaniotis:2007, Angelos Chaniotis, 'The Dynamics of Rituals in the Roman Empire,' in: O. Hekster/S. Schmidt-Hofner/C. Witschel (ed.), Ritual Dynamics and Religious Change in the Roman Empire (Leiden: Brill, 2009), 3-29.

Chapman: 2010, David W. Chapman, Ancient Jewish and Christian Perceptions of Crucifixion (Grand Rapids: Baker, 2010).

Cook:2014, John Granger Cook, Crucifixion in the Mediterranean World (Tübingen: Mohr Siebeck, 2014).

DeMaris:2008, Richard DeMaris, The New Testament in Its Ritual World (London: Routledge, 2008).

Dunn:1999, James D.G. Dunn, The theology of Paul the Apostle (Grand Rapids: Eerdmans, $\left.{ }^{3} 1999\right)$.

Eliade:1961, Mircea Eliade, Images and Symbols: Studies in Religious Symbolism (New York: Sheed \& Ward, 1961).

Elliott:1993, John H. Elliott, 'Social-scientific criticism: Perspective, process and payoff. Evil eye accusation at Galatia as illustration of the method,' HTS 67 (2011).

Elliott:1993, John H. Elliott, What is Social-Scientific Criticism? (Minneapolis: Fortress, 1993).

Elliott:1994, Neil Elliott, Liberating Paul: the Justice of God and the Politics of the Apostle (Maryknoll: Orbis, 1994).

Finney:2013, Mark T. Finney, 'Servile Supplicium: Shame and the Deuteronomic Curse - Crucifixion in Its Cultural Context,' Biblical Theology Bulletin 43 (2013), 124-134.

Flannery:2008, Frances Flannery, 'The Body and Ritual Reconsidered, Imagined, and Experienced,' in: idem/Colleen Shantz/Rodney A. Werline (ed.), Experientia 1. Inquiry into Religious Experience in Early Judaism and Early Christianity (Atlanta: SBL, 2008), 13-18.

Georgia:2013, Allan T. Georgia, 'Translating the Triumph: Reading Mark's Crucifixion Narrative against a Roman Ritual of Power,' Journal for the Study of the New Testament 36(2013), 1738.

Grimes:1990, Ronald L. Grimes, 'Infelicitous Performances and Ritual Criticism,' in: idem, Ritual Criticism: Case Studies in Its Practice, Essays on Its Theory (Columbia: University of South Carolina, 1990), 191-209.

Grimes:2004, Roland L. Grimes, 'Response to the contributions presented on the occasion of the panel "Ritual Mistakes and Failures" during the AAR conference, held in 11/2004 in San Antonio (Texas),' [unpublished].

Hawthorne:1983, Gerald F. Hawthorne, Philippians (Waco: Word, 1983).

Hellholm/Vegge/Norderval/Hellholm:2011, David Hellholm/Tor Vegge/Øyvind Norderval/Christer Hellhom (ed.), Ablution, Initiation, and Baptism BZNW 176 (Berlin: De Gruyter, 2011).

Hengel:1976, Martin Hengel, 'Mors turpissima crucis,' in: Johannes Friedrich/Wolfgang Pöhlmann/Peter Stuhlmacher (ed.), Rechtfertigung (Tübingen: Mohr, 1976), 25-84.

Hofius, Otfried Hofius, Der Christushymnus Philipper 2,6-11. Untersuchungen zu Gestalt und Aussage eines urchristlichen Psalms [Tübingen: Mohr Siebeck, $\left.\left.{ }^{2} 1991\right]\right)$.

Horsley:2005, Richard Horsley, "Introduction," in: idem (ed.), Hidden Transcripts and the Arts of Resistance (Brill: Leiden, 2005), 1-28.

Hughes:2014, Philip John Hughes, 'Dishonour, degradation and display: Crucifixion in the Romand World,' HARTS \& Minds 1:3 (2014), 2-23. 
Hüsken/Neubert:2012, Ute Hüsken/Frank Neubert, 'Introduction,' in: idem/idem (ed.), Negotiating Rites (Oxford: Oxford University, 2012), 1-17.

Hüsken:2007, Ute Hüsken, 'Ritual Dynamics and Ritual Failure,' in: idem (ed.), When Rituals go Wrong: Mistakes, Failure, and the Dynamics of Ritual 115 (Leiden: Brill, 2007), 337-366.

Ing:2012, Michael Ing, The Dysfunction of Ritual in Early Confucianism (Oxford: Oxford University, 2012).

Kertzer:1988, David I. Kertzer, Ritual, Politics, and Power (New Haven: Yale University, 1988).

Klawans:2006, Jonathan Klawans, Purity, Sacrifice, and the Temple: Symbolism and Supersessionism in the Study of Ancient Judaism (Oxford: Oxford University, 2006).

Klingbeil:2007, Gerald Klingbeil, Bridging the Gap: Ritual and Ritual Texts in the Bible (Winona Lake: Eisenbrauns, 2007).

Klostergaard Pedersen:2011, Anders Klostergaard Pedersen, 'Rituals of Purification, Rituals of Initiation: Phenomenological, Taxonomical and Culturally Evolutionary Reflections', in: David Hellholm/Tor Vegge/Øyvind Nordeval/Christer Hellholm (ed.), Ablution, Initiation, and Baptism: Late Antiquity, Early Judaism, and Early Christianity (Berlin: De Gruyter, 2011), 3-40.

Kuch:2011, Hannes Kuch, 'The Rituality of Humiliation: Exploring Symbolic Vulnerability,' in: Paulus Kaufmann/Hannes Kuch/Christian Neuhäuser/Elaine Webster (ed.), Humiliation, Degradation, Dehumanization: Human Dignity Violated (London: Springer, 2011), 37-56.

Kuhn:1982, Heinz-Wolfgang Kuhn, 'Die Kreuzesstrafe während der frühen Kaiserzeit,' ANRW II 25.1 (1982), 648-793.

Lamoreaux:2009, Jason T. Lamoreaux, 'BTB Readers Guide: Ritual Studies,' Biblical Theology Bulletin 39 (2009), 153-165.

Lieu:2004, Judith Lieu, Christian Identity in the Jewish and Greco-Roman World (Oxford: Oxford University, 2004).

Lohmeyer:1930, Ernst Lohmeyer, Die Briefe an die Philipper, an die Kolosser und an Philemon (Göttingen : Vandenhoeck \& Ruprecht, 1930).

Malina/Neyrey:1988, Bruce J. Malina/Jerome H. Neyrey, Calling Jesus Names: The Social Value of Labels Matthew (Sonoma: Polebridge, 1988).

Malina/Pilch:2006, Bruce J. Malina/John J. Pilch, Social-science Commentary on the Letters of Paul (Minneapolis: Fortress, 2006).

Marchal:2011, Joseph A. Marchal, 'Imperial Intersections and Initial Inquiries,' in: Stanley:2011, 146160.

Martin:1997, Ralph P. Martin, A Hymn of Christ. Philippians 2:5-11 in Recent Interpretation \& in the Setting of Early Christian Worship (Downers Grove: IVP, 1997)

Meeks:2006, Wayne Meeks, Christ is the Question (Louisville, KY: Westminster John Knox, 2006).

Michaels:1999, Axel Michaels, 'Le rituel pour le rituel“ oder wie sinnlos sind Rituale?,' in: Corinna Caduff/Johanna Pfaff-Czarnecka (ed.) Rituale heute: Theorien - Kontroversen - Entwürfe (Berlin: Reimer, 1999), 23-47.

Michaels:2006, Axel Michaels, 'Ritual and Meaning,' in: J. Kreinath/J. Snoek/M. Stausberg (ed.), Theorizing Rituals. Issues, Topics, Approaches, Concepts (Leiden: Brill, 2006), 247-261.

Michaels:2010, Axel Michaels, 'The Grammar of Rituals,' in: idem/Anand Mishra (ed.), Ritual Dynamics and the Science of Ritual I (Wiesbaden: Harrassowitz, 2010), 7-28.

Michaels:2012, Axel Michaels, 'A Preliminary Grammar of Newar Life-Cycle Rituals,' Journal of Hindu Studies 5 (2012), 10-29.

Moore:2006, Stephen D. Moore, Empire and Apocalypse: Postcolonialism and the New Testament (Sheffield: Sheffield Phoenix, 2006).

Moore:2011, Stephen D. Moore, 'Paul after Empire,' in: Stanley:2011, 9-23.

Müller:1988, Ulrich B. Müller, "Der Christushymnus Phil 2.6-1 1", ZNW 79 (1988), 17-44.

O'Brien:1991, Peter T. O'Brien, The Epistle to the Philippians (Carlisle : Paternoster, 1991).

Oakes:2001, Peter Oakes, Philippians: From People to Letter (Cambridge: Cambridge University, 2001). 
Oakes:2001, Peter Oakes, Philippians: From People to Letter (Cambridge: Cambridge University, 2001).

Peppard:2011, Michael Peppard, The Son of God in the Roman World (Oxford: Oxford University, 2011).

Price:1997, S.R.F. Price, 'Rituals and Power,' in: Richard A. Horsley (ed.), Paul and Empire: Religion and Power in Roman Imperial Society (Harrisburg: Trinity Press International, 1997), 47-74.

Rappaport:1999, Roy Rappaport, 'Enactments of Meaning,' in: idem, Ritual and Religion in the Making of Humanity (Cambridge: Cambridge University, 1999),104-138,

Reinbold:1994, Wolfgang Reinbold, Der älteste Bericht über den Tod Jesu (Berlin: De Gruyter, 1994). Reumann:2008, John Reumann, Philippians (New Haven: Yale University, 2008).

Samuelson:2011, Gunnar Samuelson, Crucifixion in Antiquity (Tübingen: Mohr Siebeck, 2011).

Schnelle:2003, Udo Schnelle, Paulus: Leben und Denken (Berlin: De Gruyter, 2003).

Scott:1990, James C. Scott, Domination and the Arts of Resistance: Hidden Transcripts (New Haven: Yale University, 1990).

Smit:2011, Peter-Ben Smit, 'A Numismatic Note on Philippians 2:9-11,' Biblische Notizen 149 (2011), 101-112.

Smit:2013a, Peter-Ben Smit, Paradigms of Being in Christ: Paul's Use of Exempla in Philippians (London: Bloomsbury, 2013).

Smit:2013b, Peter-Ben Smit, 'Ritual Failure, Ritual Negotiation, and Paul's Argument in 1 Corinthians 11:17-34,' Journal for the Study of Paul and His Letters 3.2 (2013), 165-195.

Smit:2013c, Peter-Ben Smit, 'War Paulus suizidal? Eine psychiatrisch-exegetische Notiz,' Biblische Notizen 158 (2013), 113-118.

Stanley:2011, Christopher D. Stanley (ed.), The Colonized Apostle: Paul through Postcolonial Eyes (Minneapolis: Fortres, 2011).

Strecker:1999, Christian Strecker, Die liminale Theologie des Paulus: Zugänge zur paulinischen Theologie aus kulturanthropologischer Perspektive (Göttingen: Vandenhoeck \& Ruprecht, 1999).

Strecker:2007, Christian Strecker, 'Macht - Tod - Leben - Körper. Koordinaten einer Verortung der frühchristlichen Rituale Taufe und Abendmahl,' in: Gerd Theißen/Petra von Gemünden (ed.), Erkennen und Erleben (Gütersloh: Gütersloher Verlagsbuchhaus, 2007), 133-153.

Streett, R. Alan Street, An Analysis of the Lord's Supper in Roman Domination during the First Century (Eugene: Pickwick, 2013)

Taussig:2009, Hal Taussig, In the Beginning was the Meal (Minneapolis: Fortress, 2009).

Thurston/Ryan:2005, Bonnie B. Thurston/Judith M. Ryan, Philippians and Philemon (Collegeville: Liturgical Press, 2005).

Uro:2010, Risto Uro 'Ritual and Christian Origins,' in: Dietmar Neufeld/Richard DeMaris (ed.), Understanding the Social World of the New Testament (London: Routledge, 2010), 220-232.

Van Henten/Avemarie:2002, Jan Willem van Henten/Friedrich Avemarie (ed.), Martyrdom and Noble Death: Selected Texts from Graeco-Roman, Jewish and Christian Antiquity (London: Routledge, 2002).

Van Henten:1997, Jan Willem van Henten, The Maccabean Martyrs as Saviours of the Jewish People: A Study of 2 and 4 Maccabees (Leiden: Brill, 1997).

Van Henten:2009, Jan Willem van Henten, 'Martyrdom, Jesus Passion and Barbarism,' Biblical Interpretation 17 (2009), 239-264.

Weder:1981, Hans Weder, Das Kreuz Jesu bei Paulus (Göttingen: Vandenhoeck \& Ruprecht, 1981).

Wright:2002, N.T. Wright, 'Paul and Caesar: A New Reading of Romans,' in: C. Bartholemew (ed.), A Royal Priesthood: The Use of the Bible Ethically and Politically (Carlisle: Paternoster, 2002), 173-193. 